\title{
Метод исторической реконструкции в исследовании эволюции градостроительной структуры поселения. Часть 2
}

\author{
Н.0.Кудрявцева, Москва \\ Л.И.Кубецкая, ЦНИИП Минстроя России, Москва
}

Остановимся на описании метода исторической реконструкции, опирающегося на анализ эволюции города и его храмовых ансамблей. В качестве основы используются: общая реконструкция плана Великого Устюга первой четверти XVII века, проведённая на топографическом плане XVIII века по летописным источникам и по данным сотных и переписных книг. Одновременно проводится хронологический анализ времени возникновения церквей и слобод на фоне сопоставления исторических планов с фиксированием новых территорий и доминант, а также текстовые данные из архивных источников превращаем в графическую информацию.

Без знания структуры, без представлений о начале, истоках и путях формирования нельзя представить модель взаиморасположения частей, а без этого не удастся выявить принципы расположения доминант, храмовой системы. Чтобы представить первозданный образ города, необходимо знание полной градостроительной системы с учётом утраченных ансамблей,

* Начало стати - см. «Academia. Архитектура и строительство», № 4, 2019 г. сложившихся в виде групп церквей. В связи с чем необходимо установить принципы сформировавшейся пространственно-композиционной системы, связанной с расположением этих групп.

Исследование начинается от истоков формирования города и последовательно выявляет взаиморасположение планировочных частей. Только после этого можно приблизиться к пониманию принципов построения доминант храмовой системы.

Об этом же говорит и Нильс Лунинг Прак, провозглашая в качестве необходимого исследование взаиморасположения частей в составе целого: «Части могут быть организованы регулярным и нерегулярным образом: вдоль оси, вокруг центра или и без того, и без другого... 0дна часть может включать в себя другую, присоединяться к ней или пересекать её» [1, с. 64]. Более того, сложение градостроительной структуры раскрывается только в эволюции, когда мы отслеживаем взаиморасположение частей и одновременное появление доминант. Историческая реконструкция эволюции градостроительной структуры городов Тотьмы, Солигалича, Тутаева и других городов показала, что композиционная система сложилась на стадии дорегулярной

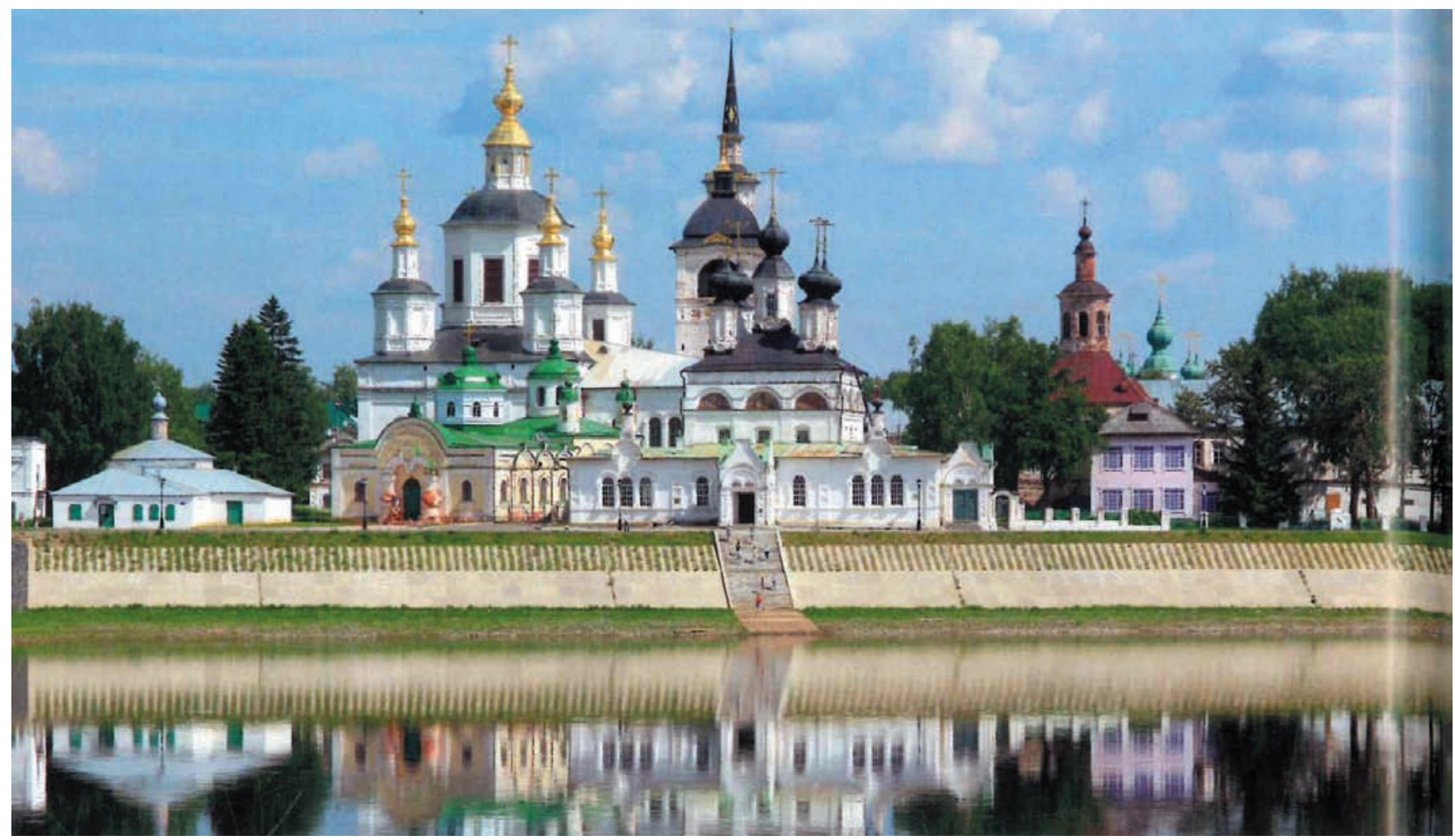

Рис. 1. Великий Устюг. Успенский собор и Соборное дворище [5, с. 22] 
планировки, опережая реализацию регулярных планов. Регулярность приводила к трансформациям и утрате морфологически ценной текстуры. Именно в силу того, что зачастую диагностика принципов, лежащих в основе построения пространственнокомпозиционной системы, проводилась на основе регулярных планов, устанавливались упрощённые схемы, например, линейной или выстроенной вдоль реки композиции города.

Новые знания в построении и развитии композиции Великого Устюга обнаруживаются только во взаимосвязи с генетическими частями города и на фоне исследования последовательности этапов эволюции градостроительной структуры города.

Первые следы зарождающегося поселения обнаружены и вблизи Соборного дворища, и вдали от реки на Красной горе [2, с. 32]. Город был основан в XII веке недалеко от места слияния рек Юга и Сухони. Первое летописное упоминание относится к 1207 году [3]. Устюжские земли не входили во владения Новгорода, а с древнейших времён подчинялись Ростово-Суздальскому княжеству. Главная и древнейшая часть - Соборное дворище - возникла на сухой удобной территории, что подтверждается фактом первоначального зарождения Устюга не в месте впадения малой реки в большую, а на возвышенном ровном плато третьей террасы. Внутри возникли Успенский собор, позднее - церковь Иоанна Устюжского (1653) и Прокопьевский собор. Почти одновременно заселялись Дымковская и Леонтьевская слободы. Село Дымково располагалось на правом берегу реки Сухона. В нём было две церкви: шатровая Дмитриевская (наиболее ранняя) и клетская Сергиевская (1739-1747). Тогда же в трёх километрах ниже по течению реки был построен Троицкий собор Гледенского монастыря. На пути между Дымковым и Гледенским монастырём ещё одна церковь - Иоанна Устюжского.

Успенский собор - главный храм Устюга - был основан как деревянная «церковь великая» ростовским архиепископом Тихоном в честь Успения Богоматери еще в 1290 году. В 1389 году он был уничтожен в результате пожара и раз- грабления, учинённых новгородцами. В 1399 году храм был построен вновь, а в 1489-ом снова сгорел. В 1491 году был заложен новый храм «не по старине», который «стал нелюб» устюжанам. В результате, к 1493 году был построен храм по типу восьмигранного столпа с четырьмя квадратнымив плане прирубами по основным осям и высоким шатром в засершении. В 1496 году и он сгорел, а в 1502-ом возведён заново по старому образцу и в 1552-ом вновь сгорел. Заново Успенский собор был возведеён на месте деревянного по указу архиепископа Ярославского и Устюжского с лета 1554-го по 1558 год. Это был первый каменный городской собор на всём Русском Севере. По размерам он был больше позднейшего. Пятиглавый шестистолпный храм повторял строительные принципы московского Успенского собора. В Смутное время Успенский собор был разорён и разграблен, поэтому его вновь восстанавливали и освятили в 1622 году. Однако в 1631-ом он опять сгорел и возобновлён в 1636 году [3, с. 7] (рис. 1). Успенский собор относится к особо редкому типу культовых сооружений - «храмы-группы».

В тот же период был основан Михайло-Архангельский монастырь (1212) (рис. 2), к которому от Соборного дворища шла улица. Через пятьдесят лет после Михайло-Архангельского возник Иоанно-Предтеченский монастырь (1262). Позднее была выстроена Рождественская церковь и подле неё выросла вторая на то время ремесленная слобода [2]. Начался этап интенсивного строительства Верхнего посада. Расположенный вблизи Спасо-Преображенский монастырь (1422) усиливал глубинное развитие композиционной системы. После упразднения монастыря в XVIII веке находившиеся на его территории холодная Спасо-Преображенская церковь (1689-1696), сходная по композиции с Михайло-Архангельским собором одноименного монастыря, и тёплая Сретенская церковь (1725-1740), напоминающая тотемские церкви и типичная для устюжского храмового строительства, стали городскими. Геометрическим композиционным центром в то время оказалась Рождественская церковь. Именно здесь

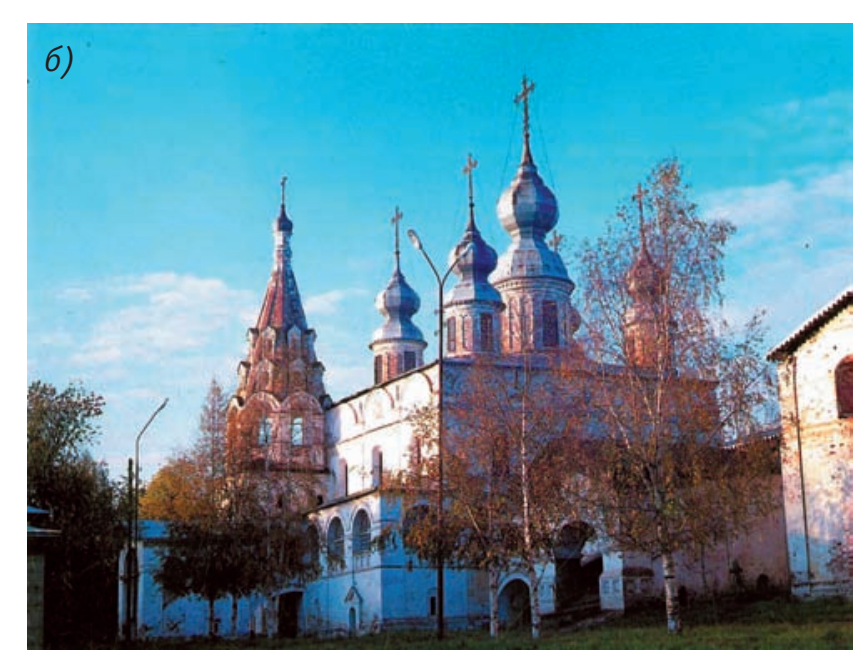

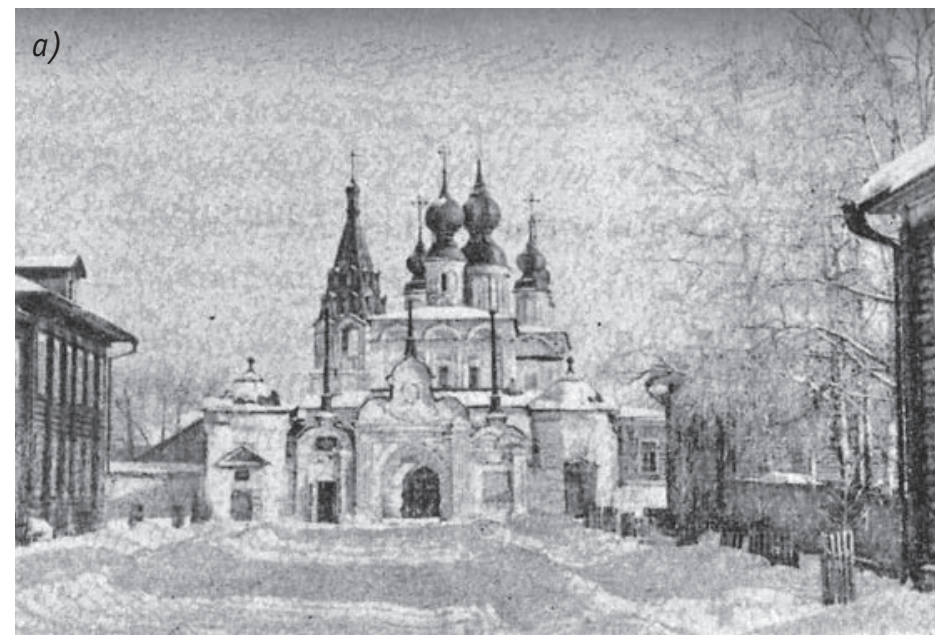

Рис. 2. Великий Устюг. Михайло-Архангельский монастырь: а) вид со стороны главных ворот. Фото 1959 года [4, с. 65]; б) Михайло-Архангельский собор. Современное фото [5, с.63] 
рядом с ней возник воеводский двор, административный центр. Сюда же с низменного участка (с запада от Соборного дворища) переместился древний торг вместе с пристанью.

Здесь же по мере развития города складывается обширный торг с восточной стороны от городища. По краю его со стороны реки построили гостиный двор, а с северной стороны - съезжую избу и посадские дворы. Этот период - от начала Соборного дворища и Леонтьевского конца до строительства Городища и перемещения к нему Торга - был началом градостроительного сложения Верхнего посада: была заложена композиционная ось, образуемая системой Дымковской и Троицкой церквей, Соборного дворища, соборами и храмами Михайло-Архангельского и Иоанно-Предтеченского монастырей (рис. 3).

Следующий этап - строительство крепости Городище в оборонных целях [6]. В нём было две церкви: Покровская и Варлаамовская. Считают, что первоначально это был монастырь-крепость. Композиция обогащалась не только за счёт групп церквей вдоль реки. В то же время существовала вторая ось, связавшая монастыри с Соборным дворищем и Дымковым и продолжившая развитие композиционной системы вдоль главной оси на север перпендикулярно реке. Определились новые пространственные связи, и закрепилась ведущая глубинная связь между монастырями и Городищенским ансамблем (рис. 4).

Строительство Городища и перемещения к нему Торга отражало невиданный торговый статус Великого Устюга, определило планировку и композицию градостроительной структуры. Это было время второго этапа градостроительного сложения Верхнего посада, в котором мощный торг закрепил место высшей городской активности и где сформировалось новое скопление церквей, расположенное глубинно по отношению к Рождественской церкви. Возникло срединное важное звено в иерархической пространственной структуре Устюга.

Сам торг оформился и планировочно - обширными торговыми рядами, вблизи которых у реки сформировался гостиный двор. Торг превратился в композиционно-планировочный ансамбль, в котором соединились три площади: посредине - обширные торговые ряды, к западу от них - ансамбль церквей Троицкой и Варваринской, с востока - церкви Воскресения (самая праздничная) и Александра Невского. Композиция развернулась вглубь - от реки к Немчинову ручью, взаимодействуя с монастырями и слободскими храмовыми ансамблями. Ближе к Городищу возникли таможня, съезжая изба. По писцовым книгам XVII века общая протяжённость укреплений Городища составила 640 м, территория внутри них - 24 га; протяжённость укреплений Большого острога - 2783 м, а площадь его - 31,5 га. За пределами оборонительных сооружений сложились комплексы монастырей Михайло-Архангельского, Иоанно-Предтеченского, СпасоПреображенского и Яиковского Филипповского монастыря. В черте городских укреплений исследователи выделяют три группы церквей: основная (первая) группа в составе Соборно- го дворища, являвшегося духовным центром города - соборы Успенский, Прокопьевский и Иоанновский, церкви Алексеевская, Козьмодемьянская и Власьевская; в Городище - По-

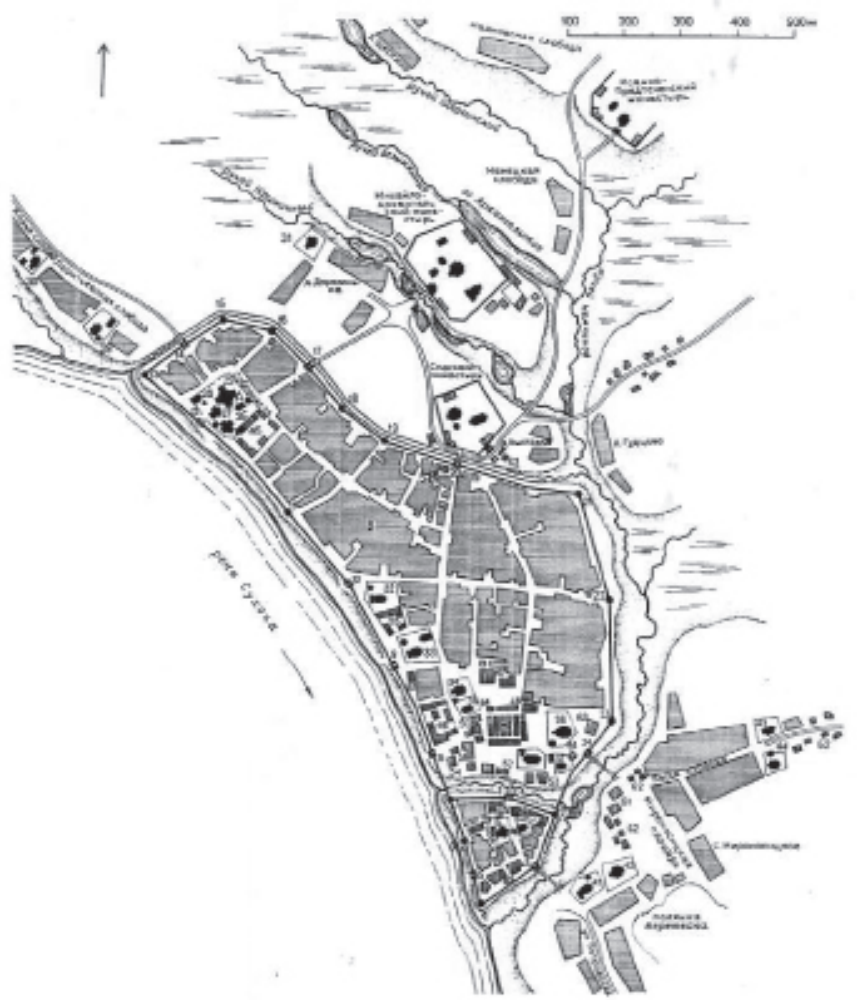

Рис. 3. Великий Устюг. Первая четверть XVII века. Схемареконструкция В.П. Шильниковской на основе обмерного плана XVIII века и летописных источников: A - Соборное дворище; Б-крепость Городище; $B$ - Верхний посад (Большой острог); Г-Михайло-Архангельский монастырь; Д-Спасский монастырь; E - Иоанно-Предтеченский монастырь; между острогом и ручьём Криночным деревеньки Деревенька и Выставка; между ручьями Криночным и Безымянным - слобода при монастыре; между Безымянным и Щергинским - немецкая слобода; за ручьём Щергинским - деревня Щергино и Ивановская слобода; на северо-западе - Козья и Леонтьевская слободы; на востоке - Пёсья слобода; на юге - Петровская; 25 - Успенский собор; 26 - Прокопьевский собор; 27 - собор Иоанна Устюжского; черкви: 28 - Власьевская, 29 - Ильинская, 30 -Леонтьевская, 31 - Воскресенская, 32 - Рождественская, 33 - Никольская, 34 - Троицкая; 35 - Варваринская, 36 - Иоанна Богослова, 37 - Александра Невского, 38 - Вознесения, 39 - Покровская, 40 - Варлаамовская, 41 - Мироносицкая, 42 - Сретенско-Мироносицкая, 43 - Борисоглебская, 44 Георгиевская; общественные здания: 45 - Владычный двор, 46-гостиный двор, 47-земские дворы, 48 - посадские дворы, 49 - торговые ряды, 50 - земские избы и схожая изба, 51 -воеводская и съезжая избы, 52 - таможенная и кабацкая избы, 53 - богадельня, 54 - баня, 55 -воеводский двор, 56 - тюрьмы, 57 - сторожевая изба; 58 - бражная изба, 59 - зелейный двор, 60 - осадные амбары, 61 - кабак, 62 - кузницы, 63 - писчая

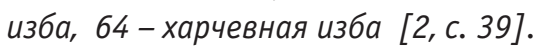


кровская, Варлаамовская и Спасская (вторая группа), третья группа - вблизи торга: церкви Рождественская, Никольская, Троицкая, Варварская, Вознесенская, Богословская, Александро-Невская [2, с. 58] (рис. 5). На территории Нижнего посада вблизи торгового центра города разместились Мироносицкая и Сретенская церкви. Были церкви при слободах вдоль дорог и на «концах» [7]. Приходские церкви, представляющие собой живописные группы, являлись местными районными центрами и подчинялись главному ядру.

Определилась и сама градостроительная структура, в которой явно отслеживаются планировочные образования со своей ориентацией и сложившейся системой улиц. На основе анализа плана, представленного в генерализованном виде Г.Я. Макеевым, авторы выделили планировочно-генетические части (рис. 6). Планировка Устюга, по его мнению, относится к веерной центрического типа [8]. На дорегулярном плане XVII века в пределах Верхнего посада Мокеев выделяет три

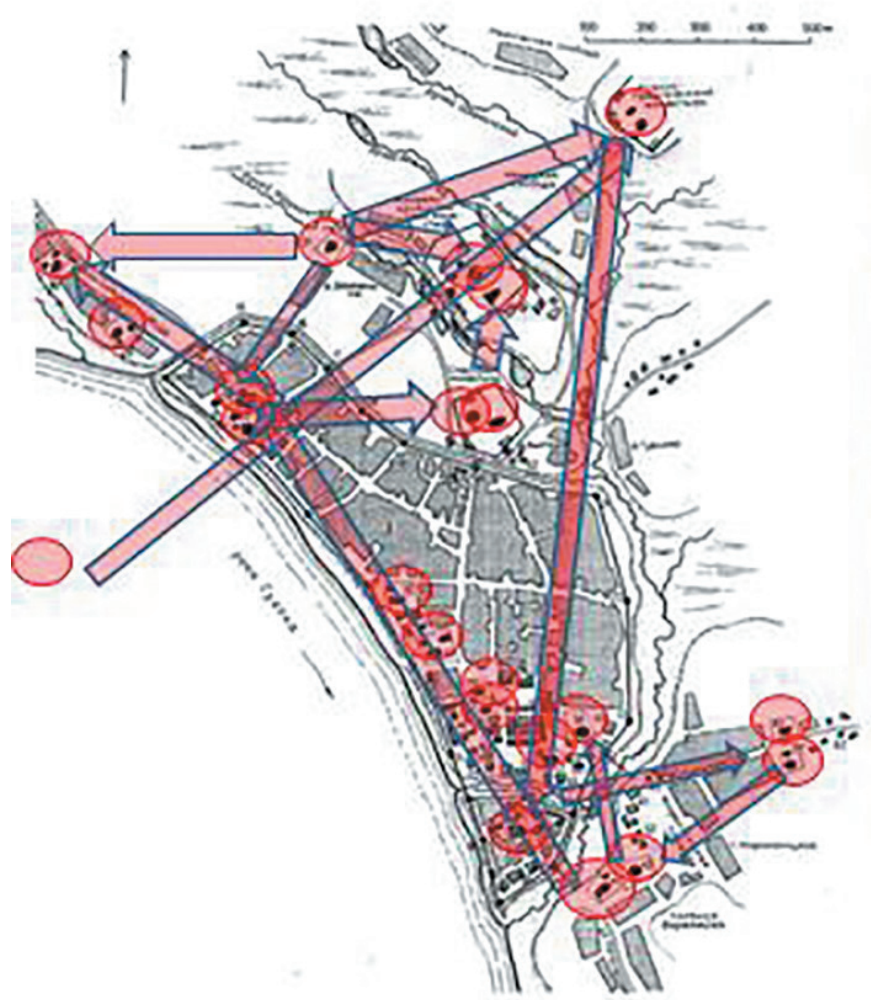

Рис. 4. Великий Устюг. Схема построения композиционных связей на плане первой четверти XVII века: A - Соборное дворище; 5 - крепость Городище; $B$ - Нижний посад; $\Gamma-M и$ хайло-Архангельский монастырь; Д-Спасский монастырь; E - Иоанно-Предтеченский монастырь; между острогом и ручьём Криночным деревеньки Деревенька и Выставка; между ручьями Криночным и Безымянным - слобода при монастыре; между Безымянным и Щергинским - немецкая слобода; за ручьём Щергинским - деревня Щергино и Ивановская слобода; на северо-западе - Козья и Леонтьевская слобода; на востоке - Пёсья слобода; на юге - Петровская веерных системы посада и две - в районе Нижнего посада. Это и закономерно: этот ранний план позволяет выявить генетические части, каждая из которых обладала собственной системой ориентации, самостоятельным принципом композиционного построения.

Торг, находясь в геометрическом центре, стал основным градообразующим ядром, предопределившим развитие градостроительной структуры и основных улиц новой радиальной системы Верхнего посада. К нему потянулись улицы и дороги, рядом с ним была сконцентрирована и общественная застройка. В двухчастной общей структуре плана определились две радиальные веерные системы, «очень сходные по принципам построения» Каждая из них включала три радиуса, два из которых подчинялись направлению реки и третий уходил «в поле» [2]. Торг стал фокусом, поляризовавшим планировку. Роль торга как организующего структурного ядра города прослеживается с античных времён ${ }^{2}$.

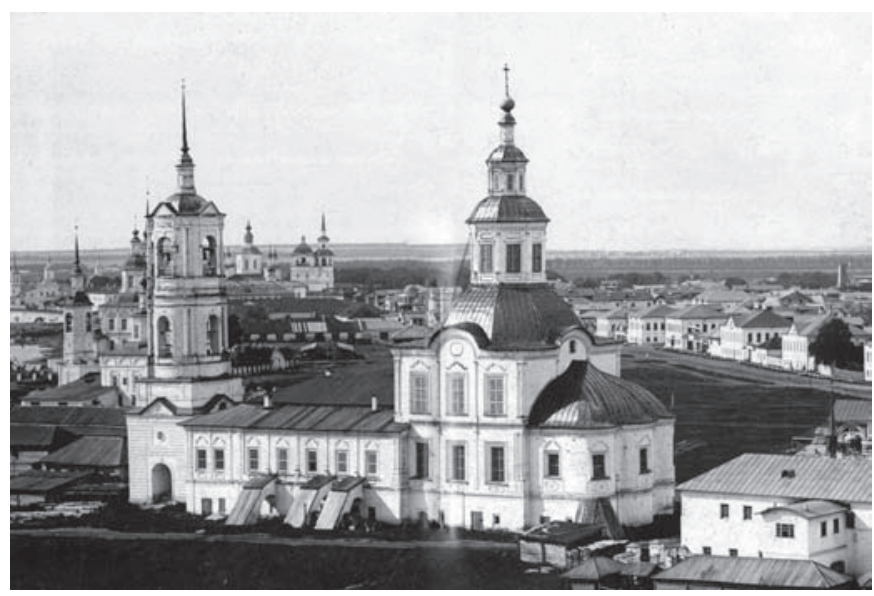

Pис. 5. Вид центральной части Великого Устюга с южной стороны. Церкви XVII-XVIII веков: Иоанно-Богословская, Троицкая, Варваринская, Никольская, за ними соборы и церкви Соборного дворища, Ильинская и Леонтьевская [3]

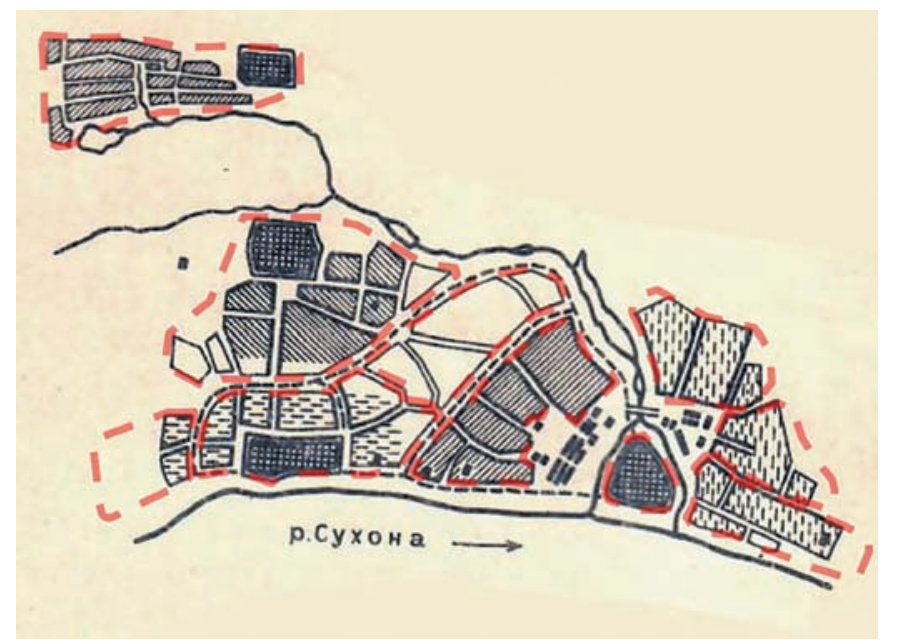

PUc. 6. Схема плана XVII века Г.Я. Мокеева и планировочногенетические части города, выявленные авторами 
К востоку от Немчинова ручья возникла площадь с ансамблем церквей и ремесленными мастерскими, с запада - на низменных территориях возникли слободы: вдоль дороги на Красноборск (Пёсья слобода) и вдоль Петровской улицы. Это был Нижний посад, а слободы образовали «восточный конец», посредством которого усиливались связи с близлежащими слободами и Гледенским монастырём. Аналогичным был и западный - Леонтьевский - конец, укоренившийся вблизи Верхнего посада на западе. Кроме того, на удобных территориях (при монастырях и между ручьями) раскинулись многочисленные деревеньки и слободы. Эта развитая градостроительная структура отражала экономическую мощь, функциональную активность, богатство и разнообразие построек.

Проанализируем морфологическое и градостроительное богатство, запечатлённое на плане межевания 1772 года³ (рис. 7). К этому времени структура города была двухчастной, в ней явно прослеживалось два планировочных ядра - композиционные центры плана. По северной границе прошла подковообразного начертания дорога, обеспечившая удобную связь восточной части города с зонами монастырей и монастырскими слободами. На плане отчётливо прослеживается гармоничная и логичная система площадей, играющих большую организующую роль. Крепость с примыкающим с запада обширным торгом Верхнего посада и ремесленной площадью Нижнего посада приобрели роль единого городского центрального ядра, создающего основу радиально-центрической градостроительной системы.

Анализируя организацию структуры - от истоков к последовательному сложению новых планировочных частей, выявляя принципы их взаиморасположения, морфологию, можно приблизиться к пониманию принципов построения доминант храмовой системы центричной градостроительной

${ }^{2}$ В Мцхете, античной столице государства Картли торг стал местом притяжения торгового населения и формирования вблизи целой еврейской колонии - района вокруг торговой площади, которая называлась «рабат» [9, с. 20].

${ }^{3}$ ЦГИАЛ. Ф. 1399. Оп. 1. Ед. хр. 290. Л. 3.

${ }^{4}$ ЦГИАЛ. Ф. 1399. 0п. 1. Ед. хр. 290. Л. 3.

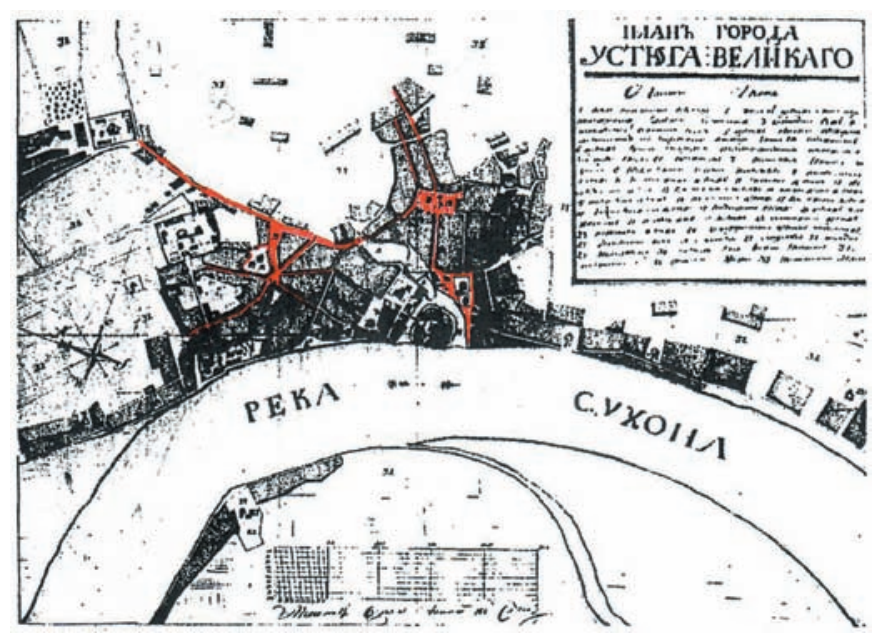

Рис. 7. Город Устюг Великий. План межевания 1772 года структуры. В ней сохранилось первоначальное многообразие генетических частей с присущим каждой своеобразием, сохранившимся от предшествующих этапов.

Дорегулярная морфология, придающая своеобразие и логичность двучастности градостроительной системы, - не случайное явление. Градостроительная система не в меньшей степени, чем «архитектура, несёт груз ответственности за полноту воплощения в своих образах, формах и пространствах

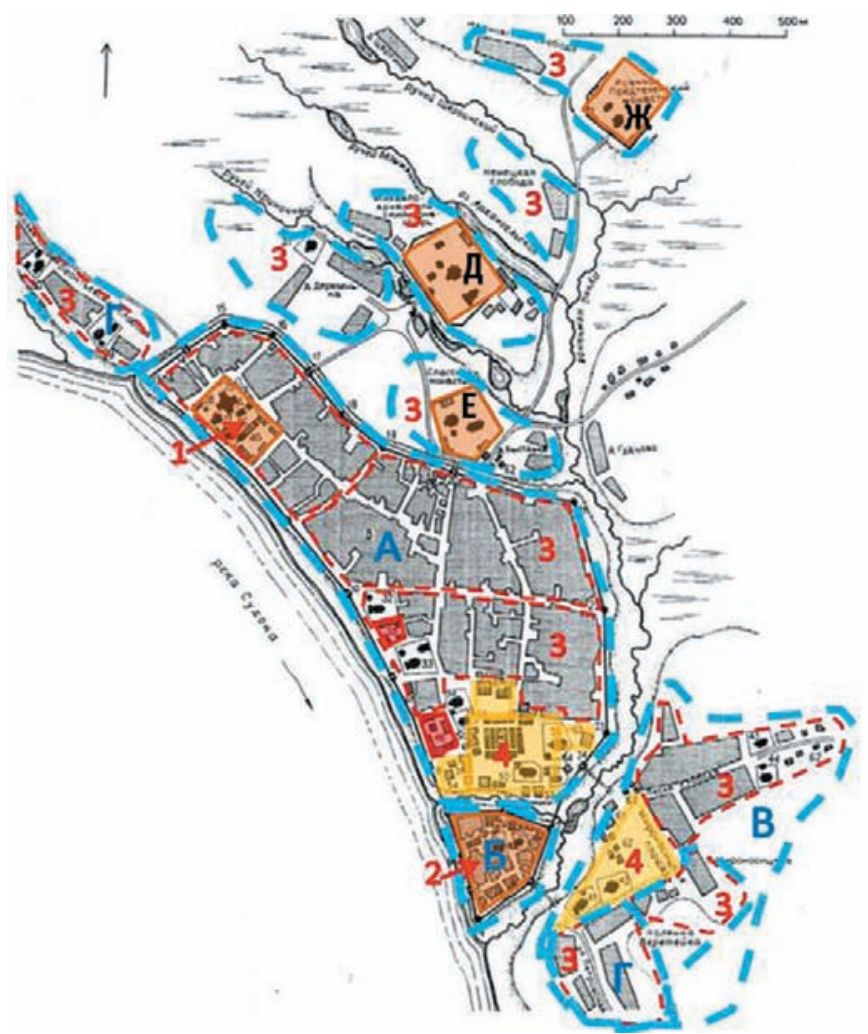

1 - Соборное дворище, 2 - административный центр, 3 деревеньки и слободы, 4 - торг -2 - -2 - 2 -
чантицыцы кенупный планировочных зон

- монастыри Михайло-Архангельский монастырь, Спасский Иоанно-Предтеченский и религиозные комплексы - торги

Рис. 8. Город Устюг Великий. Авторская схема - историческая реконструкция сформировавшихся генетических частей и комплексов. А- Верхний посад (Большой острог); Б - крепость Городище; В - Нижний посад; Г- концы; Д-Михайло-Архангельский монастырь; E - Спасский монастырь; Ж - Иоанно-Предтеченский монастырь. Деревеньки и слободы: между острогом и ручьём Криночным - деревеньки Деревенька и Выставка; между ручьями Криночным и Безымянным - слобода при монастыре; между Безымянным и Щергинским - Немецекая слобода; за ручьём Щергинским -деревня Щергино и Ивановская слобода; на северо-западе - Козья и Леонтьевская слободы; на востоке - Пёсья, на юге - Петровская 
того существенного, что свойственно пространству культуры и того, что заложено в ландшафтно-климатических условиях местности» [10, с. 12]. В тесной связи с идентичностью рассматривается и уникальность, в том числе и градостроительной идентичности.

Осознавая морфологическое богатство дорегулярной градостроительной системы Великого Устюга как категорию наследия, мы выводим понятие идентичности на уровень градостроительной структуры.

Регулярный план аннулировал первоначальную морфологию. Утрачено композиционно-планировочное направление северо-запад-юго-восток. Две композиционно значимые линии параболической конфигурации и два композиционнопланировочных фокуса утрачены. Тем самым ликвидирована двучастность плана. Для того чтобы выявить подлинную структуру проведём историческую реконструкцию её генетических частей.

Сопоставление планов дало возможность определить условные границы и взаиморасположение генетических частей градостроительной структуры - Верхнего и Нижнего посадов, крепости-Городище, монастырей, слобод. Обнаружено своеобразие, зафиксированное наличием концов - структурных образований, характерных для кончанской системы планировки. Представлена условная модель градостроительной структуры в виде соединённых в одно целое разновременных генетических частей (рис. 8).

Метод исторической реконструкции включает не только воспроизведение построения композиционной системы города или поселения в целом. Только на основе знания системы в целом можно прогнозировать новую застройку. Проводится анализ времени возведения церквей, их расположения. Выявление исторических границ генетических частей позволяет выделить посады с доминантами, установить главные взаимосвязи между Соборным дворищем,

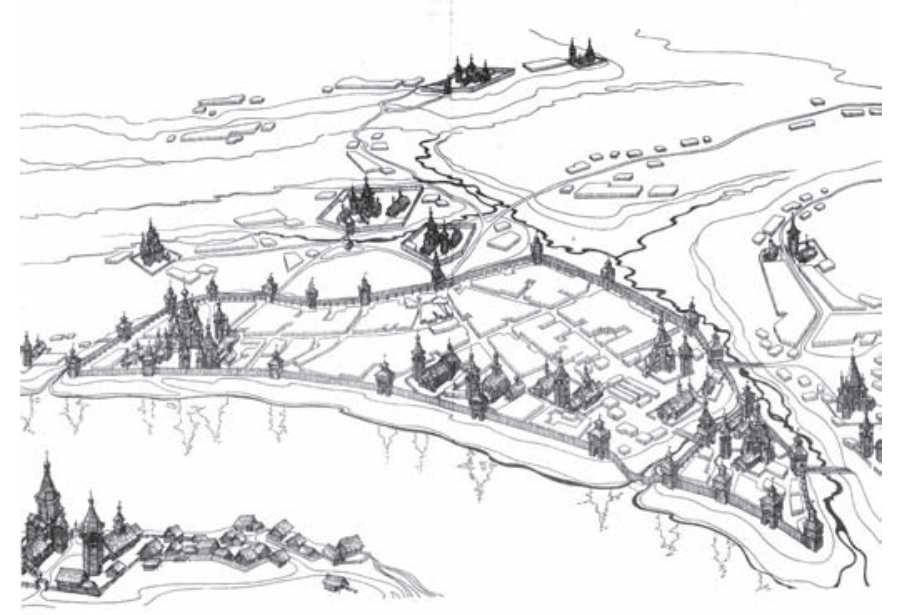

Puс. 9. Общий вид Великого Устюга в первой четверти XVII века. Реконструкция выполнена В.П. Шильниковской [2] по материалам летописных источников, сотных и писцовых книг XVII века с использованием аналогов
Михайло-Архангельским монастырём и крепость-Городищем (треугольное построение). Композиционная система города складывается из большого количества церквей: 11 церквей на посаде, две церкви в Городище, четыре церкви в Нижнем посаде, три слободские церкви на западе и севере и не менее шести церквей монастырских вне посада. Выстраивается композиция каждого храмового ансамбля: Успенский храм был окружён кольцом меньших по размеру каменных соборов: Иоанна Праведного (1656-1663, увенчанного мощным барабаном классических» форм, выполненным в 1830 году) и Прокопьевского (1668, перестроен в 1720). Оба храма выстроены по образцам монументальных храмов Ярославля. Соборная группа из трёх храмов дополняется тёплыми зимними церквями, среди которых Власьевская церковь, соборная колокольня и звонница. В XVII веке построен двухэтажный архиерейский дом (позже перестроенный).

Итак, мы видим мощный ансамбль из шести сооружений, выразительно объединяемых одним именем «Соборное дворище», - главный древнейший духовный центр и композиционная доминанта. Ниже по течению реки в направлении к городищу: Рождественская церковь (ближайшая к дворищу), рядом с которой разместился Владычный двор, далее - Никольская, Троицкая и Варваринская церкви (вблизи которой и построены были обширные торговые ряды), гостиный двор, посадские дворы. К востоку, ближе к Немчинову ручью - три доминанты: церкви Иоанна Богослова, Александра Невского и Вознесения. Они, как бы обволакивая бровку надпойменной террасы, вместе составили организующий центр композиционной системы Нижнего посада. Триединое ядро сгруппировалось вместе с церквями Городища в значительную группу, развернувшуюся к дальним монастырям на севере. Они сформировали систему, в основе которой треугольник: Дворище, Городище вместе с Торгом и цепь монастырей (рис. 9). Локальные пространственные системы, взаимодействуя между собой, расположены на более низких отметках. К XVIII веку в Городище осталась только церковь Варлаамия Хутынского. На Нижнем посаде и нижних отметках сложились свои локальные подсистемы: на площади вблизи Городища - состоящая из Мироносицкой и Сретенско-Мироносицкой церквей, в Пёсьей слободе - Антония и Феодосия Печерских, Борисоглебская, Георгиевская церкви и Симеона Столпника.

С запада к Верхнему посаду подходила Леонтьевская слобода с Ильинской и Леонтьевской церквями, за которыми протянулась Козья слобода. Эти группы и создавали свои локальные пространственно-композиционные системы.

Экономическая мощь, культурные взаимосвязи обусловили активное храмовое строительство. Множество многоярусных церквей и колоколен, по мнению Подъяпольского, расположившись вдоль реки, «то громоздятся тесной толпой, то расступаются, давая выход к воде городской застройке» [11, с. 12]. Эта кажущаяся стихия - на самом деле иерархически сложившаяся система, обращённая не только к реке Сухоне. Михайло-Архангельский мона- 
стырь, пространственно взаимосвязанный с Успенским и Прокопьевским соборами, удерживал глубинную ось. От церкви Вознесения устанавливаются пространственные взаимосвязи как с соседствующими ансамблями Спасского и Михайло-Архангельского монастыря, так и с церковью Антония и Феодосия Печерских на Нижнем посаде. То есть композиция разворачивается вглубь.

Основы построения обнаруживаются в сопоставлении этапов эволюции градостроительной структуры. Принцип расположения лучше всего раскрывается на фоне морфологической текстуры дорегулярного плана, как это и было показано ранее в анализе плана межевания Великого Устюга, на основе которого разрабатывался регулярный план.

Как мы видим, экономическое процветание города, небывалые денежные обороты - всё это нашло отражение в архитектуре храмов Устюга, главного узлового торгового пункта Севера.

Наиболее полного расцвета город достиг во второй половине XVI века в связи с установлением торгового пути в Европу через Белое море. В это время Устюг становится епархиальным центром, а к его имени официально добавляется эпитет «Великий». К началу XVII века Великий Устюг становится одним из богатейших городов Московской Руси.

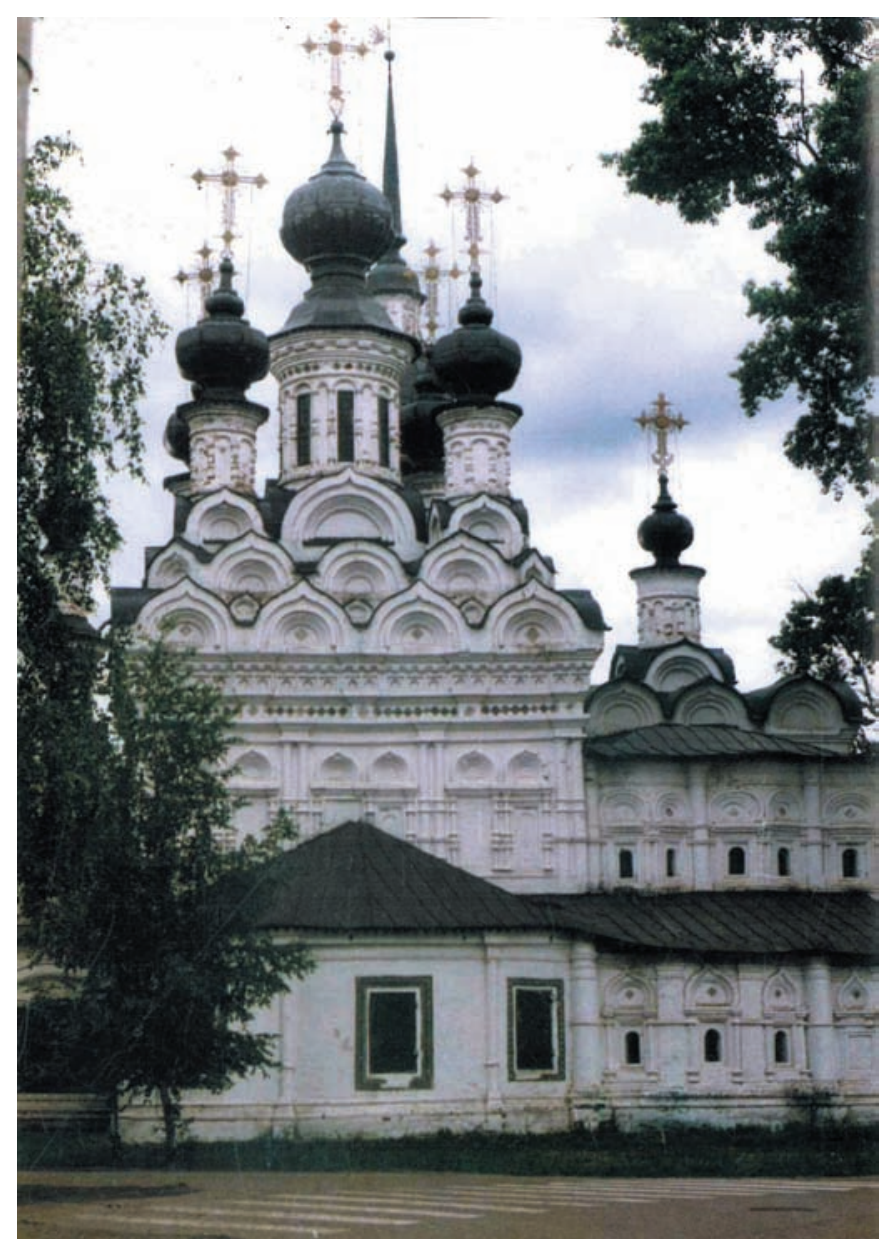

Puc. 10. Церковь Вознесения. XVII век [12]
Пересечение транзитных путей и экономическое процветание сопровождалось взаимным обменом традиций между регионами. Так, устюжане приняли соборный (купольный) тип храма, заимствованный из Ярославля (при обновлении Успенского собора). Но когда в XV веке мастер Алексей Вологжанин заложил на месте сгоревшего Успенского собора церковь «не по старине кресчату», вопреки великокняжескому указанию «такову же, какова была», устюжане вознегодовали. Пришлось мастеру заново срубить церковь «круглу по старине о двадцати стенах», то есть восьмигранную в плане с четырьмя прирубами. Вот в этом и проявляется устойчивость традиций храмового зодчества. В то же время открытость к стилевому разнообразию видим в архитектуре Вознесенской церкви, построенной в 1648 году, - самой праздничной из всех устюжских храмов. Это произведение - одно из лучших воплощений допетровского барокко. Она была построена на деньги богатого купца Никифора Ревякина, члена гостиной сотни (привилегированного сословия Русского государства), имевшего торговые дела в Москве, который выбрал в качестве аналога московскую церковь Троицы в Никитниках. Крыльца, галереи, лестница с карабкающимися арками, оформленные спаренными арками с висячими гирьками, богатый живописный декор, узорные решётки с двуглавыми орлами, многоцветные изразцы - всё создало ликующий гимн в

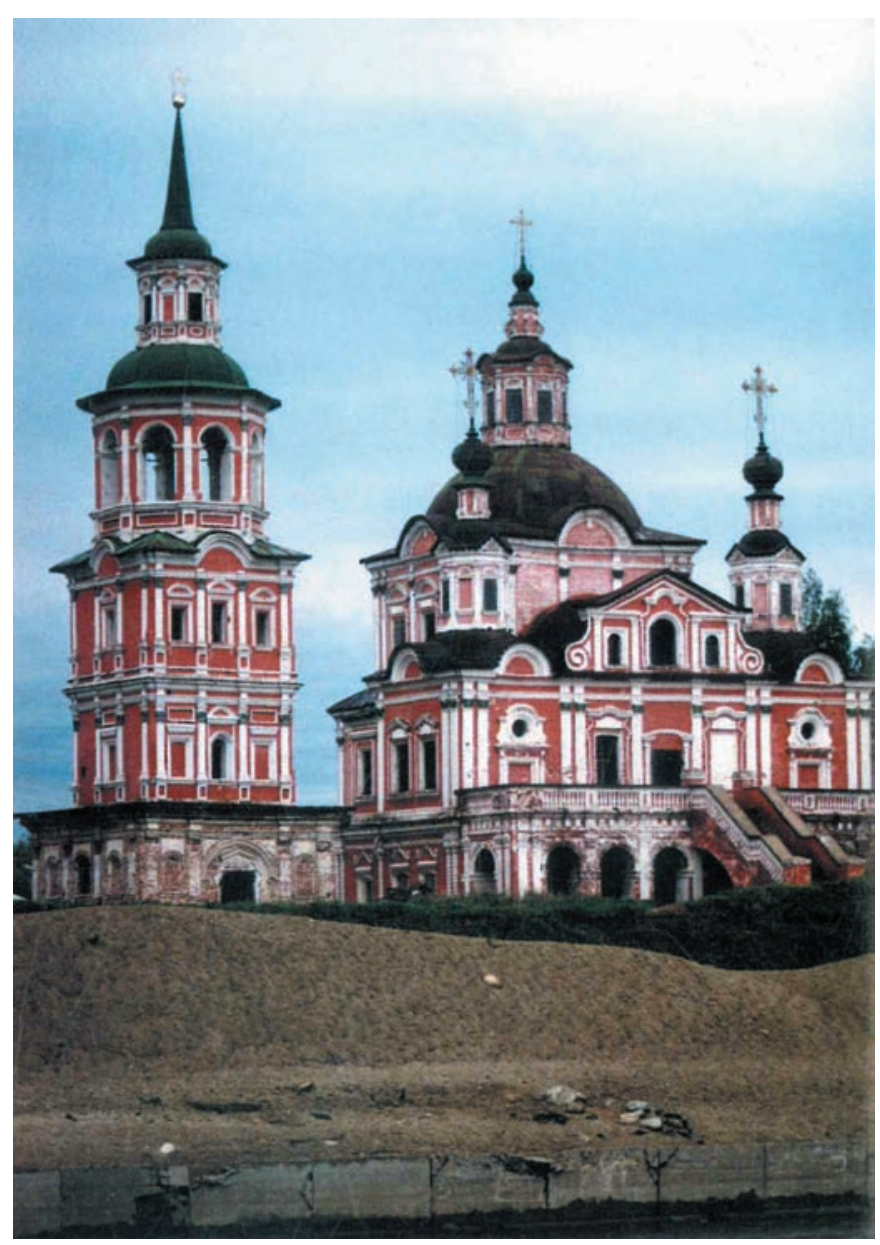

Рис. 11. Храм Симеона Столпника. XVIII век. Фото А.В. Тарасовского [12] 
архитектурном воплощении (рис. 10). Если архитектура монастырских храмов отличается изобилием традиционных форм, то церкви XVIII века имеют другие стилевые особенности и отличаются большей монументальностью и официальностью (рис. 11).

Мы видим, что метод исторической реконструкции, основанный на исследовании эволюции, необходим для понимания закономерностей сложения градостроительной структуры и пространственной системы. Он графически интерпретирует генетическую модель и принципы расположения ансамблей церквей во взаимоотношении с генетическими частями. И тогда представление о хаотической композиции Великого Устюга вытесняется стройным представлением о ней как об иерархической системе, сформировавшейся из групп на Большом посаде, взаимосвязанной с монастырями, уходящими от реки в северном направлении и развиваемой церквями «на концах» - в Леонтьевской слободе на западе и Песьей слободе на востоке. Благодаря Дымковским слободским церквям, возникшим на правом берегу реки Сухоны, - Дмитриевской (1739) и Сергиевской (1747), - система развивается и на противоположном берегу, поддерживаемая на региональном уровне Троицким собором Гледенского монастыря.

$$
* * *
$$

Уничтожение множества культовых сооружений и в целом морфологической текстуры привело кутрате ценности дорегулярной градостроительной структуры, что зачастую влечёт ошибочные представления о принципах построения города. Поэтому для градостроительных решений и прогнозов необходимо изучение эволюции градостроительной структуры малых исторических городов, и сохранение элементов дорегулярного этапа.

Историко-аналитическое осмысление эволюции системы храмовых ансамблей посредством отслеживания времени строительства церквей на фоне изучения процесса сложения градостроительной структуры выявляет особенности построения. Именно доминирующие сооружения организуют пространственную систему и выявляют наиболее значимые в композиционном и видовом значении местоположения (фокусы, узлы). Ощутимо и явно эту взаимосвязь можно проследить, используя графический анализ.

Ещё раз обобщим результаты аналитических разработок. Как показано в настоящем исследовании, изучение градостроительной эволюции и генезиса позволяет описать модель структуры поселения, состоящую из разновременных частей, возникших с древнейших времён до настоящего времени. Обнаруживается разнообразие генетических моделей, что связано с географическими факторами, административной, культурной, религиозной ролью города. Своеобразие и специфика градостроительной структуры отдельных городов обусловлены закономерностями её историко-генетического формирования, которые раскрываются в процессе изучения эволюции с использованием представленной методики.

Метод исторической реконструкции, рассматриваемый как эволюционный, даёт развёрнутую картину сложения и раз- вития пространственно-временной историко-генетической модели. Одновременно происходит выявление принципов взаимного расположения генетических частей и построения пространственно-композиционной системы, а также и самих приёмов формирования ансамблей.

Метод основывается на графическом воспроизведении описей писцовых книг, происхождении топонимов, сопоставлении разновременных планов, отчётов и прочее из истории строительства сооружений.

Разработанный метод исторической реконструкции позволяет воспроизводить во всей полноте градостроительную структуру, обнаруживать древние специфические элементы, без которых нельзя установить принципы планировочной и пространственной организации [13].

Метод исторической реконструкции позволяет восстановить древние части градостроительной структуры, в частности так называемые «концы» Устюга Великого - Леонтьевский, включавший две слободы, и Пятницкий. Концы характеризовались полуаграрным укладом жизнедеятельности и тем не менее осуществляли огромную организующую роль на прилегающих внегородских территориях и поселениях.

В Устюге мы выявили сложную двухуровневую систему композиционных построений - относительно обособленных, самостоятельных в пределах Верхнего и Нижнего посадов, и второго порядка - на уровне слобод, дальних частей, раскрывающихся при пердвижении. Они находятся в соподчиненном взаимодействии - как малая и большая системы.

Историческая реконструкция градостроительной структуры даёт представление и знания:

- об исторической (пусть даже частично утраченной) роли таких городов, как Каргополь, Муром, Трубчевск, Владимир, Ярославль;

- о полной пространственно-временной модели разновременных генетических частей и их взаиморасположении;

- о параметрах, модульности градостроительной структуры;

- о принципах историко-генетического сложения градостроительной структуры (выброс вдоль радиальных направлений и заполнение между ними);

- о принципе, лежащем в основе построения композиционной системы;

- о генетическом коде.

Выявлены непоправимые утраты градостроительного наследия Устюга Великого, причинённого жёстким насильственным введением регулярной планировки, нивелирующей границы, разнообразие и различия историко генетических частей, которые отчетливо видны на дорегулярных планах.

Исследование выводит на новое понимание реконструкции, реализуемой не столько на единичном элементе, сколько на градостроительной структуре, в целях компенсации богатства морфологии, упрощённого и утраченного в результате реализации регулярных планов. То есть недопустимо упрощение морфологии в результате расчистки территории 
в процессе реализации генерального плана. Реконструкция должна производиться широкомасштабно, возвращая изначально присущие градостроительной структуре дорегулярные морфологические элементы. Возможны корректировки современных решений ради восстановления исторических планировок и параметров исторической среды. Бывшие слободские улицы, где доминирует природный фактор, не следует подчинять универсализации из-за действующих нормативов, необходимо выбирать варианты современных дублёров улиц по внешним зонам.

Считаем целесообразным рекомендовать реконструкцию и даже возобновление изначально присущих градостроительной структуре частей и морфологтчески ценных элементов. Новое строительство должно быть частью процесса реконструкции. Представляет интерес способ возвращения характерных дорегулярных конфигураций для размещения в них отдельных комплексов, стилистически и образно созвучных историческим образцам, в целях повышения плотности застройки отдельных зон, а также участков нового строительства. Результаты проведённой реконструкции должны служить основой выбора методов, приёмов и типологических характеристик новых и восстановливаемых элементов строительства.

Историческая реконструкция - это не только восстановление первоначальных качеств и параметров ансамблей, но и границ генетических частей (даже утраченных), составляющих подлинную целостную историко-генетическую модель поселения как объекта охраны. Подобная основа необходима для проведения градостроительного зонирования по историко-генетической ценности территории в целях строгого установления режимов и регламентов нового строительства. Реконструкции должны подлежать не только объекты, но и градостроительная структура. С помощью метода исторической реконструкции возможно моделирование развития и воссоздания градостроительной структуры на историкогенетической основе, в которой заложен генетический код органического роста.

\section{Литература}

1. Прак, Нильс Лунинг. Язык архитектуры: очерки архитектурной теории / Нильс Лунинг Прак. - Москва : Дело, 2017. - 282 с.

2. Шильниковская, В.П. Великий Устюг. Развитие архитектуры города до середины XIX в. / В.П. Шильниковская// М. : Стройиздат, 1987. - 140 с.

3. Мальцев C.К. Великий Устюг: сохранённое и утраченное / С.К. Мальцев. - Вологда : Древности Севера, 2010. - 159 с..

4. Тельтевский, П.А. Великий Устюг / П.А.Тельтевский. - М. : Государственное издательство по строительству, и строительным материалам, 1960. - 152 с.

5. Верхов, С.И. Великий Устюг. Путеводитель / С.И. Верхов. - Вологда : Великоустюгский историко-архит.и художеств. музей-заповедник, 2019. - 80 с.
6. Бочаров Г.Н. Сольвычегодск. Великий Устюг. Тотьма / Г.Н. Бочаров, В. Выголов. - М. : Искусство, 1983. - 336 с.

7. Черкасова, М.С. Концы на Устюге в Средневековье и раннее Новое время / М.С. Черкасова // История и культура Ростовской земли. - Ростов-на-Дону, 2014. - С. 5-12.

8. Мокеев, Г.Я. Планировка древнерусских городов и методика раскрытия её систем / Г.Я. Мокеев // Источники и методы исследования памятников градостроительства и архитектуры : сб. науч. тр. / под ред. А.В. Рябушина // Центр. н.-и. и проект. ин-т по градостроительству. - М. : Стройиздат, 1980. - Cc.

9. Апакидзе, А. Города Древней Грузии / А. Апакидзе. Тбилиси : Мецниереба, 1968. - 296 с.

10. Есаулов, Г.В. Об идентичности в архитектуре и градостроительстве / Г.В. Есаулов // Academia. Архитектура и строительство. - 2018. - № 4. - С. 12-18.

11. Подъяпольский, С.С. По Сухоне и Северной Двине / С.С. Подъяпольский. - М. : Искусство, 1969. - 126 с.

12. Великий Устюг : краеведческий альманах. Вып. 3 / Гл.ред. М.А. Безнин. - Вологда : Русь, 2004. - 392 с.

13. Кубецкая, Л.И. Историко-генетические закономерности формирования градостроительной структуры и ценностное зонирование территории поселений / Л.И.Кубецкая // Устойчивое развитие территорий : Сб. докладов Первой международной научно-практической конференции. Москва, 16 мая 2018; МГСУ. - М. : МГСУ, 2018. - С. 207-212.

\section{References}

1. Prak, Nil's Luning. Yazyk arkhitektury : ocherki arkhitekturnoi teorii [Language of Architecture : Essays on Architectural Theory]. Moscow, Delo Publ., 2017, 282 p.

2. Shil'nikovskaya, V.P. Velikii Ustyug. Razvitie arkhitektury goroda do serediny XIX v. [Velikii Ustyug. The development of city architecture until the middle of the XIX century]. Moscow, Stroiizdat Publ., 1987, 140 p.

3. Mal'tsev S.K. Velikii Ustyug: sokhranennoe i utrachennoe [Great Ustyug: saved and lost]. Vologda : Drevnosti Severa Publ., 2010, 159 p.

4. Tel'tevskii, P.A. Velikii Ustyug [The Great Ustyug]. Moscow, Gosudarstvennoe izdatel'stvo po stroitel'stvu, i stroitel'nym materialam Publ., 1960, 152 p.

5. Verkhov, S.I. Velikii Ustyug. Putevoditel' [Great Ustyug. Guide]. Vologda, Velikoustyugskii istoriko-arkhit.i khudozhestv. muzei-zapovednik Publ., 2019, 80 p.

6. Bocharov G.N., Vygolov V. Sol'vychegodsk. Velikii Ustyug. Tot'ma [Solvychegodsk. Velikii Ustyug. Totma]. Moscow, Iskusstvo Publ., 1983, 336 p.

7. Cherkasova, M.S. Kontsy na Ustyuge v Srednevekov'e i rannee Novoe vremya [Ends on Ustyug in the Middle Ages and Early New Time]. Istoriya i kul'tura Rostovskoi zemli [History and culture of the Rostov land]. Rostov-on-Don, 2014, pp. 5-12.

8. Mokeev, G.Ya. Planirovka drevnerusskikh gorodov $i$ metodika raskrytiya ee sistem [Thelayout of ancient Russian 
cities and the methodology of disclosing its systems]. In A.V. Ryabushin (ed.) Istochniki i metody issledovaniya pamyatnikov gradostroitel'stva i arkhitektury [Sources and methods of research of monuments of urban planning and architecture]: sb. nauch. tr. Moscow, Stroiizdat Publ., 1980.

9. Apakidze, A. Goroda Drevnei Gruzii [Cities of Ancient Georgia ]. Tbilisi, Metsniereba Pudl., 1968, 296 p.

10. Esaulov, G.V. Ob identichnosti $v$ arkhitekture $i$ gradostroitel'stve [On identity in architecture and urban planning ]. Academia. Arkhitektura i stroitel'stvo [Academia. Architecture and construction], 2018, no. 4, pp. 12-18. (In Russ, abstr.in Engl.)

11. Pod"yapol'skii, S.S. Po Sukhone i Severnoi Dvine [according to Sukhon and the Northern Dvina]. Moscow, Iskusstvo Publ., 1969, 126 p.
12. In M.A. Beznin (ed.) Velikii Ustyug : kraevedcheskii al'manakh [The Great Ustyug: local history almanac], Vyp. 3. Vologda, Rus' publ., 2004, 392 p.

13. Kubetskaya, L.I. Istoriko-geneticheskie zakonomernosti formirovaniya gradostroitel'noi struktury i tsennostnoe zonirovanie territorii poselenii [Historical and genetic patterns of the formation of the urban structure and value zoning of the territory of settlements]. Ustoichivoe razvitie territorii [Sustainable development of territories] : Sb. dokladov Pervoi mezhdunarodnoi nauchno-prakticheskoi konferentsii. Moscow, May 6, 2018. Moscow, MGSU Publ., 2018, pp. 207-212.

Кубецкая Любовь Ивановна (Москва). Старший научный сотрудник ЦнИИП Минстроя России (проспект Вернадского, 29. цНИИП Минстроя России. E-mail: kubeckayal@mail.ru.

Кудрявцева Наталия Орестовна (Москва). Ph.D. Архитектор. E-mail: designbyaspect@yahoo.uk.com.

Kubetskaya Lyubov Ivanovna (Moscow). Senior Researcher at Institute for Research and Design of the Ministry of Construction and Housing and Communal Services of Russia (29 Vernadskogo avenue, Moscow, 119331. TsNIIP). E-mail: kubeckayal@mail.ru.

Kudryavtseva Natalia Orestovna (Moscow).Ph.D. Architect. E-mail: designbyaspect@yahoo.uk.com. 